\title{
Remembering William Faulkner's Address Upon Receiving the Nobel Prize for Literature
}

\begin{abstract}
William Faulkner was awarded the Nobel Prize in literature for the year 1949. He officially received the Prize and delivered his acceptance speech on December 10, 1950. This article re-examines critical responses to the writer's Nobel Prize address, their interest in the address's intertextual references to Faulkner's earlier works and the works of other writers. The language of the address documents significant aspects of Faulkner-the writer's/Faulkner-the reader's aesthetic vision from the perspective of his didactic concern with the duties of the writer facing the challenges of his/ her time and as a means of constructing publicly Faulkner's own literary self-portrait of universal dimensions.
\end{abstract}

Keywords: Nobel Prize, intertextuality, didacticism, self-referentiality.

The year 2020 will mark the seventieth anniversary of William Faulkner's becoming the recipient of the Nobel Prize in literature for 1949, the official statement of the Swedish Academy having been delayed until November 10, 1950. It may be seen as a sign of the award's and the writer's prestige that Faulkner's critical biographers have taken interest in the anecdotal aspects of the distinction and of the celebration itself. As for its many other winners, the public profile the Prize ensures was for Faulkner an honor that let him, a professional shape-shifter, assume the posture of one who must always put personal autonomy above worldly recognition. A correspondent of Dagens Nybeter learned from the laureate that he was not planning to go to Stockholm, as Stockholm was too far away from the farm "down here" in Mississippi where his, the farmer's, primary obligations were (Gray 309, Karl 806). Once he did go there, however, the pride of having his high international status acknowledged was inseparable from the need to distance himself from it by emphasizing the provincial location of his work down on the map of his native country. In a letter to a friend, Faulkner wrote: "I fear that some of my fellow Mississippians will never forgive that $30,000 \$$ that durn foreign country gave me for just sitting on my ass writing stuff that makes my own state ashamed to own me" (Faulkner, Novels 1926-1929, "Chronology" 1163). Far away from his farm, Faulkner seemed to find refuge from the officialdom of the ceremony by posing as a Mississippian: "It was as long as a Mississippi funeral," he told the reporters (Minter 219). The anecdotal in Faulkner's biographies invariably has its dark side: in 1949 Faulkner's affair with Joan Williams, not much older than his daughter, became a source of distress and anguish rather than of peace and satisfaction; neither farming nor writing could bring relief to the troubles and uncertainties of Faulkner's domestic life; in 1950 the hunt in the Delta following the news of the Nobel Prize was the time of heavy drinking which may or may not have helped Faulkner forget that, by establishing a solid stature in literary history, prizes of such renown tend to allow the shadow of the writer's younger 
self darken the vision of possible future accomplishment. One could argue that it was the disquieting thought of his becoming a distinguished figure of the past, a writer who cannot help staring back at his own established canon, that dictated to Faulkner some famous lines in the text of the Nobel Prize address he delivered in the fall of 1950.

Faulkner's Nobel Prize acceptance speech (now available online) had all the features of Faulkner's "splendid failure." It proved that Ernest Hemingway was right when five years later, having found a good excuse for not going there himself, he asked the American ambassador to Sweden to read his acceptance speech in which he said that "a writer should write what he has to say and not speak it" (Baker 806). In the banquet hall Faulkner, unshaven and visibly uncomfortable, stood too far away from the microphone to be clearly heard and understood. Hurrying, slowing down, hesitating, making awkward pauses, his soft voice with a deep Southern accent drew attention to itself because it spoke of the writer's shyness and nervousness and not because its modulations helped convey the meaning of the words. Perhaps Faulkner's oral performance was listened to with interest and anticipation as a great writer's way of rehearsing the text that could only become significant by being read when printed.

The text of the speech addressed the fears of the present day from a global perspective. Faulkner spoke of the threat of a nuclear conflict in the Cold War era: "Our tragedy today is a general and universal physical fear for so long sustained that we can even bear it. There are no longer problems of the spirit. There is only the question: When will I be blown up?" The "I" in the question shifted emphasis from individual vision to collective experience. Powerful as it was meant to be, when written rather than when spoken, the directness of the question seems somewhat unFaulknerian, especially when compared with a much more spirited tone of the "I" from the opening sentence of the address where the importance of the writer's life is judged on the basis of the writer's work: "I feel that this award was not made to me as a man but to my work-." The question which presupposes annihilation, negation, silence is also the question which preconditions the writer's passion for words (and the award it may eventually bring to the writer: "the purpose and the significance of its [the Nobel Prize's] origin"). This paradox is already highly Faulknerian, also in the sense of recognizing its rootedness in the tradition of literary responses to moments of historical crisis, declarations of faith (Faulkner's "I decline to accept the end of man;" "I believe that man will not merely endure: he will prevail") that literary texts can and should have impact beyond literary contents and contexts.

What Nathaniel Rich has recently written of another American Nobel Prize winner, Saul Bellow, would also apply to Faulkner's appearance in Stockholm in 1950: he was "describing his new position in American culture: insisting on the writer's need for independence from worldly affairs while throwing himself into them" (Rich 26). It is not easy, however, to appreciate Faulkner's concern with the "tragedy" of the feared global annihilation when it takes the form of a didactic, if not prescriptive, pronouncement on the art of writing, a pronouncement which is not immune to grandiloquence and rhetoric and which, because of the writer's and the

1 Quotations from Faulkner's Nobel Prize acceptance speech come from "Address upon Receiving the Nobel Prize for Literature" in The Portable Faulkner, ed. Cowley, 723-724. 
award's prestige, is so sure of being given a pre-eminent position. "Using this moment as a pinnacle from which I might be listened to by the young men and women already dedicated to the same anguish and travail," Faulkner is telling them what they "must learn" or "relearn," what they "must teach [themselves]," what they must accept as the only thing worth writing about. Then and only then, one of them will "some day stand here where I am standing."

Not surprisingly, Faulkner scholars have had little patience with the laureate's preaching skills and a rather forceful rhythmic arrangement of the sometimes selfcontradictory message sent from the elevation of the speaker's pulpit to those whose "griefs grieve on no universal bones, leaving no scars." In Richard Gray's The Life of William Faulkner: A Critical Biography we find less than ten sentences on Faulkner's address and the strenuous punctuation in one of them may be seen as an indication of the critic's troubled position: "The fame of the Nobel Prize acceptance speech has, by now, perhaps blinded us to the fact that it is, at best, a glorious piece of windy oratory: that tries to make up in term of rousing cadences for what it lacks in substance" (310).

The fact that some Faulkner scholars devote more space to Faulkner's speech in Stockholm may result not so much from their readiness to accept its obtrusive moralistic rhetoric and its inflated claims for originality ("to create out of the materials of the human spirit something which did not exist before") as from the recognition of its capacity to offer an illustration of the trajectory of Faulkner's work and its relatedness to the works of other writers he read and re-read. When Gray asks himself the question "but how did all those references to "the old verities and truths of the heart, the old universal truths' fit in with a book like The Sound and the Fury?" (310), he means that in aesthetic terms these references failed in formulating what the book succeeded in dramatizing. The question points to the need of making the connection between the address and the book, but, out of respect for Faulkner's mature work, the critic feels no need to expand on it. Faulkner readers will easily notice that the "rousing cadences" of his Nobel Prize speech owe much to the "successive waves" of the preacher's voice on April 8", 1928 in The Sound and the Fury, the voice whose "virtuosity" made the congregation forget the speaker's insignificant appearance, the voice which seemed to "consume" the speaker and the congregation as "their hearts were speaking to one another in chanting measures beyond the need for words" (Faulkner, Novels 1926-1929 1104). In Faulkner's speech, as in the novel published twenty years earlier, the words did continue to exercise their cumulative effect until they could be sure of making the most of the repetition of the favorite one in the writer's lexicon- "to endure."

While the preacher in Jefferson "sounded like a white man" when he rose to speak, Faulkner's voice in Stockholm, according to Frederick R. Karl, sounded like the black man's and it spoke of the "Negro" with the same force as it did in Intruder in the Dust from 1948:

For those who seemed surprised at the positive nature of the speech, Intruder, in fact, had already said it all. There Faulkner spoke of the Negro's ability to 'wait and endure and survive' until the white Southerner gives him his just rights economically and politically. In the speech, he took up this theme and brought it to a more universal application. For his sense of man's survival, he clearly had the Southern Negro as his model. As we see Faulkner position himself in race 
relations in Mississippi and the South, for him the ability to prevail and endure belongs to the Negro - and in his Nobel Speech, the Negro is at the center of his mind, at the center of the universe. (815)

Karl's critical comment sounds convincing insofar as for the center of the writer's mind we can take the universal quality of language which, as Faulkner imagined that quality in The Sound and the Fury and in Intruder in the Dust, allows the white and the black voices to speak in unison, preferably beyond the audible.

It would be more realistic and less didactic to look for the correspondences between the language of Faulkner's Nobel Prize speech and the language of the story which links the liberating hunting experience with the horror of racial history. In "The Bear," published in 1942 in Go Down, Moses, hunting is also writing. People can claim to own the land no more than they can claim to own the language, which is timeless and which belongs to all. The hunting places are the places of storytelling and of listening. So are, though not as good as the big woods ("bigger and older than any recorded document"), the libraries and plantation offices. The opening pages of "The Bear" tell the young men (young women are absent there), with as much intensity and dedication as the text of the Nobel Prize speech, what they must learn in order to become worthy of taking their place among the elevated company, among those who already feel and know what to believe, what to decline, what to refuse. The ritualistic incantation of ancient virtues to be slowly acquired and then rigorously followed in the wilderness - "the will and hardihood to endure and the humility and skill to survive" (Faulkner, Novels 1942-1954 140) — are echoed in the Nobel Prize speech, repetitively and with growing strength, by listings of "universal truths" a writer must possess and be possessed by in order to overcome the fear threatening to make "a life's work" meaningless: "the courage and honor and hope and pride and compassion and pity and sacrifice, which have been the glory of his past." Young McCaslin must laboriously, in agony and in sweat, learn to read the signs in the family documents revealing to him, word by word, record by record, not the glory but the horror of the historical past, the truth which the timeless hunter's/writer's virtues will help him endure. In "The Bear" Faulkner emphasizes that whenever the best of all talking and the best of all listening began " $[t]$ here was always a bottle present." Whisky, he writes, should be drunk by hunters "not with the pagan's base and baseless hope of acquiring thereby the virtues of cunning and strength and speed but in salute to them" (141). The use of negation to make the affirmative resound with increased force is one of the trademarks, or, to use his own word "tricks," of Faulkner's stylistic method in the story. In the camp, during the annual deer hunt in the fall of 1950, did Faulkner remember these verbal patterns when he might have been thinking about the way to salute in Stockholm the art of writing which is practiced "not for glory and least of all for profit" and the award which, like the hunter's trophy, is given to him "in trust" only?

The formulations from the Nobel Prize address appear in A Fable, the first parts of which Faulkner had begun to send to Random House in 1946 and which he published as a novel in 1954. Though set in France months before the end of World War I, A Fable refers to World War II and the impending nuclear war in the decade following it. It tells of the burden of negotiating between the authoritarian power of the enslaving military system and the idealistic desire to maintain the virtues of individualism and free will, 
the desire which one could associate with the powers of expression. The language of the novel, like the language of the Nobel Prize speech, lacks dramatic immediacy. As Lothar Hönninghausen observed in Faulkner: Masks and Metaphors: "Like mystery plays, moralities and political parables, $[$ A Fable $]$ comprises a series of didactic units or stations, unfolding not in narrative progression but like tableaux vivants or film stills" (151). This, of course, makes the text of the novel recognizably Faulkner's, reminiscent of the successful use of the same technique in his best novels. The problem with the language of $A$ Fable, mirrored in the Nobel Prize speech, was that, relying heavily on its moral purpose, it found consolation from political as well as artistic uncertainties, in the domain of abstractions. In the Nobel Prize speech, Faulkner raises the already high-flown level of the rhetoric by substituting the verb "to endure" by the verb "to prevail," without, however, giving up the opportunity to explain expansively (and with a literary flourish that reminds the reader of his early work), that "to endure" would "merely" mean: "that when the last ding-dong of doom has changed and faded from the last worthless rock hanging tideless in the last red and dying evening, that even then, there will still be one more sound: that of the puny inexhaustible voice, still talking." "I refuse to accept this," says Faulkner. In A Fable, Faulkner's savior-like voice creates a vision of other planets being militarized, a warning more developed than in the speech but one to be equally valued for the effectiveness of its cumulative articulation:

\begin{abstract}
Oh yes, he will survive it because he has that in him which will endure even beyond the ultimate worthless tideless rock freezing slowly in the last red and heartless sunset, because already the next star in the blue immensity of space will be already clamorous with the uproar of his debarkation, his puny and inexhaustible and immortal voice still talking, still planning; and there too after the last ding dong of doom has rung and died there will still be one sound more: his voice, planning still to build something higher and faster and louder, more efficient and louder and faster than ever before, yet it too inherent with the same old primordial fault since it too in the end will fail to eradicate him from the earth. I don't fear man. Faulkner (Faulkner, Novels 1942-1954 994).
\end{abstract}

The ease and a certain degree of pleasure we can find in discovering intertextual dependencies of Faulkner's speech on his writings takes us back again to the anecdotal and darker aspects of the ceremony honoring the author. Although, as he said, he was going to speak about his work rather than about himself, one may still wonder to what extent the writer was sincere in mentioning, or, in fact, giving it a pivotal role in the design of the speech, the historical fact of threatened peace (the unmentioned reality of the Soviet blockade in Berlin and the Korean War). When he spoke of the need to create something that "did not exist before," was he summoning the spirit of modernity of resurrecting the body of modernism? Was William Faulkner really addressing young men and women who, knowing and rejecting fear, should responsibly follow him in their choice of literary themes, or was he actually addressing himself, the writer who felt dissatisfied with his work in a more mature but less hopeful way that he had felt dissatisfied with it at the beginning of his literary career, the time of his splendid failures? Growing old and more assured of the significance of his work, did Faulkner want young men to listen to him, or was he talking to the younger Faulkner? Did 
the fact that his daughter, Jill, was listening to him during the Nobel Prize ceremony remind him of the presence, back in his native country, of Joan Williams, a young woman he was in love with and resolved to help in her literary career, knowing also that in doing so, he would be helping his own work?

As early as in 1945 in The Portable Faulkner (the revised 1967 edition of which would include the Nobel Prize address), Malcolm Cowley had to some extent anticipated these questions when he emphasized close links between Faulkner's particular novels and the writer's practice "to understand the present in terms of the past." That practice linked Faulkner also to other writers, among whom Cowley favored Nathaniel Hawthorne. Like Faulkner (and "like a hunter behind a rock," as Cowley wrote), Hawthorne knew how to listen to the voices of his native land and how to transcribe the "moral fables" they told into his own art, albeit "more cautiously than Faulkner... with more form and less fire" (Cowley xxix). The form which the moralistic strain took in Joseph Conrad's writing may then have proved even more appealing to the author of the Nobel Prize acceptance speech. Frederick R. Karl, who was also the author of Joseph Conrad: The Three Lives, was the first to notice correspondences between Faulkner's way of addressing the man enduring and prevailing (in the last sentence of the speech: "The poet's voice need not merely be the record of man, it can be one of the props, pillars to help him endure and prevail") and the language of Conrad's 1897 preface to The Nigger of the "Narcissus" where the writer speaks "to the subtle but invincible conviction of solidarity that knits together the loneliness of innumerable hearts, to the solidarity in dreams, in joy, in sorrow, in aspirations, in illusions, in hope, in fear, which binds men to each other, which binds together all humanity - the dead to the living and the living to the unborn" (Karl 813). Taking into consideration the sentiments of the Nobel Prize speech and their re-formulations in A Fable, equally striking may be the similarities between these and Conrad's 1917 preface to Nostromo in which he wrote of his own and his characters' "conflicting emotions" and "the secret purposes of their hearts revealed in the bitter necessities of the time" (Conrad xli).

As the title of his critical study promises, in Faulkner and Hemingway: Biography of a Literary Rivalry (2012) Joseph Fruscione finds in Faulkner's Nobel Prize speech a confirmation of its reliance on the formulations of another writer not in terms of a shared aesthetic and moral vision but in terms of opposition. That opposition, to be sure, is also quick to recognize the strengths of the opponent's work which for a writer of Faulkner's stature make it justifiable to address on such a formal and elevated occasion. This does not convince. In his pursuit of symptoms of "psychocompetitive" anxiety of influence, Fruscione wants to believe that in addressing artists as young men and women who might one day receive the Prize, Faulkner was implicitly alluding to Hemingway who deserved it without deserving it. Speaking of the "human heart in conflict with itself," Faulkner spoke of his own heart rather than Hemingway's (in his own acceptance speech recorded in Havana in 1954 Hemingway would also speak of what is in the writer's "heart," pronouncing the word "heart" in such a way that it could almost be heard as "art"). Neither does it seem convincing that for his speech in Stockholm the year the award was "made" for him and not for Hemingway, Faulkner should choose, denotatively or connotatively, a reference to a conversation between 
Frederick Henry and Gino in A Farewell to Arms. Unlike Hemingway's character who was famously declaring words such as glory, courage, honor, sacrifice to be "obscene", although he did say them with a measure of satisfaction prognostic of the moralistic strain in The Old Man and the Sea, Faulkner made his listings of abstract words considerably and intentionally longer; he found them as appropriate for the Stockholm occasion as they were in his writings, and yet, perhaps, in need of the supportive company of the texts of great writers he kept reading and re-reading. The drive to read Faulkner's and Hemingway's speeches as embodiments of "a linguistic opposition" (which in itself may be helpful in defining Faulkner's style) makes Fruscione, at the end of his argument in the Nobel Prize section of his book, seek the balance of a broader and more universal perspective in a somewhat questionable style: "Despite their differences and digs at each other in their speeches, Faulkner and Hemingway were both devoted craftsmen" (169).

Faulkner's trust in the originality of his work, the trust supported by his joining in the ranks of Nobel Prize recipients, allowed him to approach the question of literary indebtedness and borrowings not with a sense of anxiety but with a sense of freedom displaying characteristic features of his posing and role-playing stylized practices. The writer who defended the right of literature to speak openly about its moral function told undergraduate students of the University of Virginia in 1957 that a writer also has the right to be "completely amoral":

He takes whatever he needs, wherever he needs, and he does that openly and honestly because he himself hopes that what he does will be good enough so that after him people will take from him, and they are welcome to take from him as he feels that he would be welcome by the best of his predecessors to take what they've done. (Gwynn 20-21)

Another paradoxical quality about the writer's statements, induced by the fame his work received abroad rather than in his native country, was the declared awareness that the writer's natural need to read, to absorb and to accept as truly his own the texts of other writers coincides with the idea of anonymity in the republic of letters. The veil of anonymity, like the veil of abstract words calling for the recognition of literary correspondences, interconnections, resonances, quotations, both hides and communicates the need for absolute privacy and the satisfaction of the highest public acclaim. Not many months before he received the Nobel Prize, and perhaps already expectant of it, Faulkner wrote to Cowley that it was his "ambition" not to leave a mark in history as "a private individual" but as the author of his work. William Faulkner would like to have the honor of leaving his printed books unsigned, "like some Elizabethans" (Cowley, The Faulkner-Cowley File 126).

No names of writers, of the past, of the present, or of the future, are given in Faulkner's Nobel Prize acceptance speech. It was only for the editorial purposes of the volume titled The Faulkner Reader (1954) that Faulkner let readers know that when during his Nobel Prize address he said that he believed it was the writer's privilege "to help man endure by lifting his heart," he was using the words of another Nobel Prize recipient, the Polish writer, Henryk Sienkiewicz. 


\section{Works Cited}

Baker, Carlos. Ernest Hemingway: A Life Story. Harmondsworth: Penguin Books, 1972. Print.

Conrad, Joseph. Nostromo: A Tale of the Seaboard. London: Everyman's Library, 1992. Print.

Cowley, Malcolm. The Faulkner-Cowley File: Letters and Memories, 1944-1962. New York: The Viking Press, 1966. Print.

Cowley, Malcolm, ed. The Portable Faulkner. Harmondsworth: Penguin Books, 1977. Print.

Faulkner, William. Novels 1926-1929: Soldier's Pay, Mosquitoes, Flags in the Dust, The Sound and the Fury. New York: The Library of America, 2006. Print.

- Novels 1942-1954: Intruder in the Dust, Requiem for a Nun, A Fable. New York: The Library of America, 1994. Print.

Fruscione, Joseph. Faulkner and Hemingway: Biography of a Literary Rivalry. Columbus: Ohio State University Press, 2012. Print.

Gray, Richard. The Life of William Faulkner: A Critical Biography. Cambridge: Blackwell Publishers, 1996. Print.

Gwynn, Frederick L., and Joseph Blotner, eds. Faulkner in the University: Class Conferences at the University of Virginia. Charlottesville: University of Virginia Press, 1959. Print.

Hönnighausen, Lothar. Faulkner: Masks and Metaphors. Jackson: University Press of Mississippi, 1997. Print.

Karl, Frederick R. William Faulkner: American Writer. A Biography. New York: Ballantine Books, 1989. Print.

Minter, David: William Faulkner: His Life and Work. Baltimore: The John Hopkins University Press, 1980. Print.

Rich, Nathaniel. "Swiveling Man." The New York Review of Books LXVI, March 21April 9 (2019): 26-28. Print. 